Glick, D. 1949. 'Techniques of histo- and cytochemistry. Interscience Publ. New York.

Gomori, G. 1952. Microscopic histochemistry. Univ. Chicago Press. Chicago.

Goodwin, R. H., and C. J. Avers. 1956. Studies on roots. III. An analysis of root growth in Phleum pratense using photomicrographic records. Amer. Jour. Bot. 43: $479-487$.

Jensen, W. A. 1956. The cytochemical localization of acid phosphatase in root tip cells. Amer. Jour. Bot. 43: $50-54$.

Novikoff, A. B. 1955. Histochemical and cytochemical staining methods. In Analytical cytology. Ed. R. C. Mellors. MeGraw-Hill Book Co. New York.
Perner, E. S. 1953. Die Sphärosomen (Mikrosomen) pflanzlicher Zellen. Protoplasma 42: 457-481.

Seligman, A. M., and A. M. Rutenberg. 1951. The histochemical demonstration of succinic dehydrogenase. Science 113: 317-320.

Sinnotr, E. W., and R. Bloch. 1939. Cell polarity and the differentiation of root hairs. Proc. National Acad. Sci. (U.S.) 25: 248-252.

Sorokin, H. P., And S. Sorokin. 1956. Staining of mitochondria with neotetrazolium chloride. Amer. Jour. Bot. 43: 183-190.

Wilson, K. S., And V. M. Cutter, Jr. 1955. Localization of acid phosphatase in the embryo sac and endosperm of Cocos nucifera. Amer. Jour. Bot. 42: 116-119.

\title{
THE CYTOLOGY OF DEVELOPMENT AND GERMINATION OF RESTING SPORES OF SYNCHYTRIUM BROWNII ${ }^{1}$
}

\section{B. T. Lingappa}

Previously, the author (1958a, b) reported that the planospores of Synchytrium brownii Karling which do not evolve sexually function as zoospores and give rise to evanescent prosori, sori and sporangia, whereas those which differentiate into gametes fuse and form zygotes. This article concerns the development of the zygotes from infection to maturity as resting spores, their dormancy, and germination ( fig. 1-49).

As has been described for the zoospores, the content of the zygote enters the epidermal cell of the host, Oenothera biennis, leaving behind its membrane and oil globule (fig. 9). Multiple infections occur frequently. The appearance, location and growth of the zygotes in the host cell during the first day after infection are similar to those of the incipient prosori (fig. 9, 10), but the zygotes retain safranin more avidly than the latter. During the first day of their development, the nuclei appear as deeply stained bodies surrounded by finely granular and dense protoplasm (fig. 10). The nucleolus, nuclear cavity, and nuclear membrane are clearly distinguishable two days after infection (fig. 11). Then, four to six characteristic vacuoles appear in the protoplasm along the outer perimeter of the nucleus (fig. 11). These increase in size and number and give the protoplasm a foamy appearance; deep-staining granules are visible within them (fig. 12). Such vacuoles were

${ }^{1}$ Received for publication February 28, 1958.

Part of a doctoral thesis (Purdue University, 1957). The investigation was carried out under the direction of Dr. J. S. Karling, to whom I am very grateful for help and encouragement received throughout four years of work in his laboratory. Thanks are due to my wife, Yamuna, and to Dr. Ralph W. Ames for critical suggestions, and to Messers Donald J. Mason and John W. Greenawalt for taking the electron micrographs. This study was supported by a grant from the Nalional Science Foundation and a David E. Ross Fellowship of the Purdue Research Foundation. not observed in the incipient evanescent prosori and, therefore, their presence distinguishes the zygotic thalli during the first four days. However, they gradually disappear after the fourth day. From the third day onward, development of the crown or lunate body at one side of the nucleolus, the vacuolation of the nucleolus and extrusion of the chromatic granules into the protoplasm take place (fig. 11-15), as described for the evanescent prosorus by the author (1958a). The exospore appears to be discontinuously striate or lamellate by the ninth day (fig. 15). By the twelfth day at $27^{\circ} \mathrm{C}$., the resting spores appear mature (fig. 16). The chromatic granules extruded from the nuclei into the cytoplasm apparently develop into masses of coarser granules (fig. 19). In the mature resting spore, the nucleus contains a lightly stained, eccentric, vacuolate nucleolus and a compact lunate body (fig. 16). The latter consists largely of faintly stainable filaments in which a few beaded chromatic filaments are dispersed.

The incipient resting spores appear under the microscope as hyaline or whitish spherules with smooth hyaline walls and globular contents. Between the eighth and twelfth days, the exospore becomes progressively yellow and ultimately burntorange; the surface appears warty, because of the adhering host cell residue (fig. 21-31). The mature resting spores appear dirty grey in reflected light and burnt-orange under the microscope. During the development of the evanescent prosori, large orange-yellow globules begin to appear, from about the fourth day, so much so that the mature prosori appear bright-orange. In contrast, the globular contents of the resting spores are lightcream colored and large orange-yellow oily glob. ules appear only after the initiation of the incipient sori during the germination of the resting spores.

A single host cell may contain one to five resting 


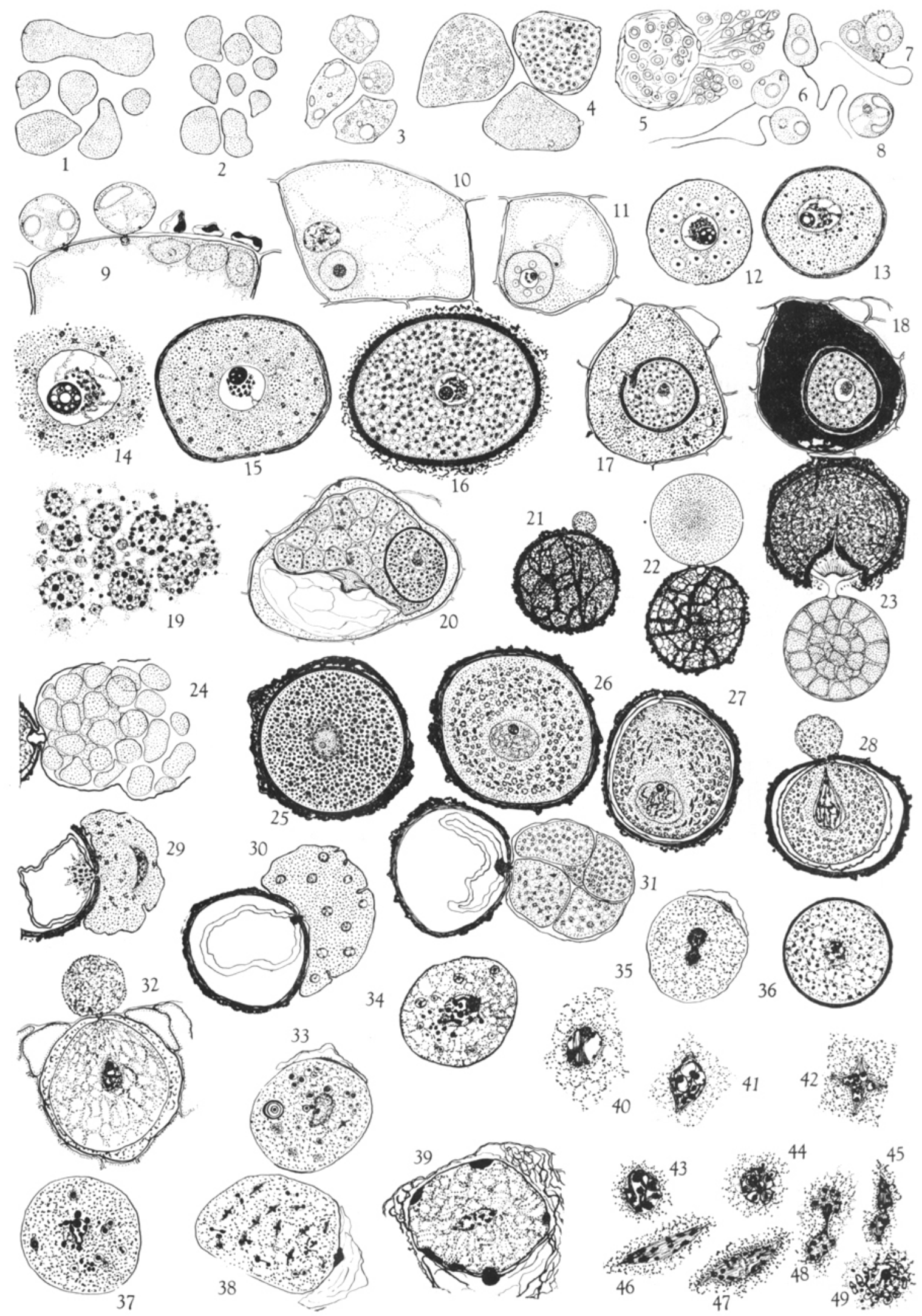


spores. The resting spores do not fill the host cells, and the remainder of the infected host cell is usually filled with a yellow- to dark-brown host cell residue. Occasionally, resting spores and evanescent prosori are found within the same host cell (fig. 20). In such cells, the dense and deeplystaining residue which appears to be a characteristic host reaction to the presence of the resting spores (fig. 17, 18) does not occur.

Frequently, very unusual resting spores, which appear as chalky white spots in reflected light, occur amidst the normal brownish spores. They have thick, hyaline and smooth exospores, and colorless and globular contents. In fixed and stained preparations, their contents resemble those of the evanescent prosori except that the coarse cytoplasmic granules are more abundant. In the normal resting spores, the dense masses of discrete clusters of coarse granules are very prominent, and the network of ground protoplasm is only faintly visible (fig. 19), whereas in the evanescent prosori, the coarse granules are few and less conspicuous, and the protoplasm is more prominent. Furthermore, the contents of the evanescent prosori stain predominantly with fast green, while the contents of the white spores stain differentially with safranin, like those of the normal resting spores. The residue around such spores is very finely granular and compact and fills the rest of the host cell. Unlike the residue around the normal resting spores, it is colorless and takes the plasma stains. In other respects, such as size and general appearance, they resemble the normal resting spores. Thus, they seem to be intermediate between resting spores and evanescent prosori. Their germination has not been observed, and their origin and function are unknown. They were first considered as aborted spores, but the appearance and stainability of their protoplasm and nuclei do not permit such an interpretation.

Although diploid, unlike $S$. endobioticum (Curtis, 1921), the resting spores of $S$. brownii are not distinguishable from the evanescent prosori by their larger nuclei. The mature evanescent prosori average $100 \mu$ with nuclei $26 \mu$ in diameter. The resting spores, on the other hand, average $60 \mu$ with nuclei $16 \mu$ in diameter. These observations on $S$. brownii are similar to those of Rytz (1907) on the nuclei of $S$. succisae.

GERMINATION OF THE RESTING SPORES. - The rest-

Fig. 1-49. The cytology of development and germination of resting spores of Synchytrium brownii--Fig. 1-9 and 21-24 were drawn from living preparations.-Fig. 1. Sporangia derived from evanescent prosorus. $\times 250 .-$ Fig. 2 . Sporangia from germinated resting spore. $\times 250 .-$ Fig. 3 . Immature sporangia. $\times 250$. Fig. 4. Stages of sporogenesis. $\times 500,-$ Fig. 5. Emergence of planospores. $\times 500$.-Fig. 6 . Active planospores. $\times 1500 .-$ Fig. 7 . Copulating gametes. $\times 1500$. - Fig. 8. Zygote. $\times 1500$. - Fig. 9. Infecting zygotes. $\times 2000$. - Fig. 10. One-day-old zygote, lying below the host nucleus. $\times 800 .-F i g .11,12$. Three- and 5-day-old zygotic thalli. $\times 1000 .-$ Fig. 13 . Seven-day-old zygotic thallus. $\times 400$.- Fig. 14. Nucleus of 9-day-old zygotic thallus. $\times 800 .-F i g .15,16$. Ten- and 14-day-old resting spores. $\times 500$. -Fig. 17, 18. Fourteen-day-old resting spores, enveloped by loose or compact host cell residue. $\times 250 .-$ Fig. 19 . Cytoplasmic aggregates of resting spores. $\times 1800,-$ Fig. 20. Resting spore and a sorus in the same host cell. $\times 250$. Fig. 21-24. Stages of germination of resting spores.-Fig. 21. Initiation of vesicular cytoplasmic outgrowth. $\times 250$. -Fig. 22. Well-developed vesicle or incipient sorus. $\times 250$.-Fig. 23 . Slightly crushed spore, showing relation of plug, thick endospore, exospore and sporangiosorus. $\times 250 .-F i g .24$. Dehisced sorus; germinated spore was left undisturbed for 20 days on moist agar plate. $\times 250 .-$ Fig. 25-31. Cytology of germinating resting spores.-Fig. 25 . Dormant spore. $\times 500 .-F i g .26$. Nuclear and cytoplasmic changes during early stages of germination. Uniformly fine granular protoplasm appears along the periphery and around the nucleus. Deeply-staining cytoplasmic aggregates are decreasing in size and number. $\times 500 .-F i g .27$. Initiation of exit papillum. The displaced nucleus contains prominently beaded chromatic filaments. $\times 500 .-$ Fig. 28. Cytoplasm migrating outward to form incipient sorus. Endospore contracting. $\times 500$ - - Fig. 29. Orientation of the primary nucleus in the incipient sorus. $\times 400 .-F i g$. 30. Multinucleate incipient sorus. $\times 500 .-$ Fig. 31 . Incipient sporangiosorus. In the sporangia nuclear divisions are still in progress. This sorus contains a fewer number of sporangia as compared to those shown in fig. 23 and $24 . \times 500$. - Fig. $32-49$. Abnormal cytology.-Fig. 32. Extrusion of prosoral content outside of the host cell. Cytoplasm vacuolate and moribund. The nucleus is pyknotic, without membrane. $\times 500 .-$ Fig. 33 . Primary nucleus of incipient sorus is disorganized and groups of bodies which resemble secondary nuclei, or macro- and micronuclei appear in its vicinity. Air-dried before fixing. $\times 500$.-Fig. 34. Simulating development of secondary nuclei from chromidia extruded from primary nucleus. Incipient prosorus, exposed to $60^{\circ} \mathrm{C}$. for $1 \mathrm{hr}$. $\times 250 .-$ Fig. 35 . Pyknotic primary nucleus of incipient sorus, simulating amitotic division. Exposed to $60^{\circ} \mathrm{C}$. for $1 \mathrm{hr}$. before fixing. $\times 250$. Fig. 36 . Nucleus in degenerating resting spore which was exposed to $60^{\circ} \mathrm{C}$. for $1 \mathrm{hr}$. before fixing. Nuclear membrane is not evident. $\times 300 .-F i g$. 37. Pyknotic nucleus simulating nuclear gemmation. Incipient prosorus which was immersed in distilled water for $12 \mathrm{hr}$. at $27^{\circ} \mathrm{C}$. $\times 250$.-Fig. 38. Pyknotic secondary nuclei simulate simultaneous occurrence of mitotic and amitotic divisions. Incipient sorus, air-dried before fixing. $\times 250 .-F i g .39$. Incipient sorus degenerating due to destruction of neighbouring host cells by parasitic fungus. Nucleus is pyknotic, cytoplasm moribund and the wall has developed plug-like ingrowths. $\times 250$.

Fig. 40. Pyknotic primary nucleus simulating intranuclear spindles. Prosorus air-dried before fixing. $\times 700 .--F i g$. 41-44. Pyknotic primary nuclei simulating heteroschizis or endomitoses. In prosori, air-dried before fixing. $\times 500$.Fig. 45. Pyknotic primary nucleus simulating amoeboid constriction. In prosori, in herbarium material. $\times 500 .-$ Fig. 46, 47. Pyknotic primary nuclei simulating regular mitotic divisions. Prosori exposed to $60^{\circ} \mathrm{C}$. for $1 \mathrm{hr}$. before fixing. $\times 600 .-F i g .48$. Pyknotic primary nucleus simulating amoeboid constriction and heteroschizis. In prosorus killed by sulfur spray. $\times 500 .-$ Fig. 49. Pyknotic primary nucleus $\mathbf{n}$ degenerated resting spore, simulating nuclear gemmation or multiplication by chromidia. From a leaf lesion caused by $\mathrm{CuSO}_{4}$ solution. $\times 450$. 
ing spores were germinated on plates of 3 per cent plain agar as described by the author (1955). As reported by Karling (1954), they germinate as prosori and give rise to superficially attached sori of sporangia. They germinate readily at $15-30^{\circ} \mathrm{C}$. under water as well as on a wet surface. The various stages of germination have already been described by the writer (1955). So far, no physical or chemical stimuli have been found to break the dormancy of the resting spores.

When large numbers of one-year-old resting spores are placed in water at $20^{\circ} \mathrm{C}$., a few of them germinate within a fortnight. Germination continues under those conditions as long as there are viable spores. In such preparations, dormant resting spores were present along with germinating spores for 3 years. This indicates that dormancy may be very short or extremely prolonged. The resting spores taken immediately after maturityi.e., 15 days after infection - when placed under favorable conditions did not germinate even after 4 months but they appeared to be healthy. However, if they were air-dried for more than a month and then placed in water, some of them hegan to germinate after 3 weeks. Three-year-old resting spores, taken from herbarium specimens, began germinating within a fortnight. The resting spores did not germinate above $30^{\circ} \mathrm{C}$. and were not viable after exposure to $60^{\circ} \mathrm{C}$. for one hour.

The dormant resting spore has a thick burntorange exospore, a thin hyaline endospore, a large primary nucleus and dense, deep-staining and coarsely granular cytoplasmic aggregates (fig. 25) . The nucleus, $14-25 \mu$ in diameter, contains a homogeneous nucleolus $(5-10 \mu)$ and a compact lunate body. Prior to germination, the cytoplasmic ag. gregates which lie in the immediate vicinity of the endospore gradually disappear and are replaced by finely granular dense protoplasm (fig. 26). During this transition, the cytoplasmic aggregates become spindle-shaped or bacilliform, progressively decrease in size, and ultimately disappear (fig. 27). This suggests that they are used during germination. Shortly thereafter, the finely granular protoplasm below the endospore gradually becomes hyaline and homogeneous. This homogeneous substance may contribute to the thickening of the endospore (fig. 26-31). This was evidenced by the fact that at the time of germination, the homogeneous protoplasmic area is replaced by the greatly thickened, hyaline and homogeneous endospore. In fixed and stained preparations, the endospore takes plasma stains very avidly and has a wavy and shrunken outline (fig. 29-31). Although the exospore is $3-4 \mu$ thick, the endospore becomes $4-6 \mu$ thick prior to germination.

Concomitant with the changes in the protoplasm around the primary nucleus and the thickening of the endospore, the peripheral protoplasm becomes transformed into a papillate area at one point below the endospore (fig. 27). At the same time, the primary nucleus moves to the periphery of the spore (fig. 27). It contains a lightly stained nucleolus and a few beaded chromatic filaments. The latter are dispersed in dense achromatic filaments which fill the nuclear cavity during this stage (fig. $26,27)$. The tip of the papillate area abutting the endospore soon protrudes through a narrow pore formed in the spore membranes. The peripheral displacement of the primary nucleus followed by its gradual movement toward the exit and migration into the incipient sorus are essentially the same as described for the evanescent prosori of $S$. brownii by the author (1958a). However, no evidence of a conspicuous cytoplasmic organoid in relation to the migrating primary nucleus has been found in the germinating resting spores. The development of the incipient sorus, migration of the nucleus in the prophase stage, and its orientation in the incipient sorus are also similar to what has been described for the evanescent prosori (fig. 28-31). Prior to division, the primary nucleus shrinks, its outline becomes undulate and somewhat lenticular (fig. 29). A few lumpy chromatic bodies are present in the narrow nuclear cavity. Further stages of division of the primary nucleus have not heen observed, but, up to this stage, the changes in its shape and content are similar to those of the primary nucleus in the incipient sorus derived from the evanescent prosorus. On this basis, it is assumed that the division is indirect and probably meiotic, as Kusano (1930b) described for S. ful. gens, but meiosis has not been observed. The secondary nuclei in the incipient sori, as well as in the sporangia, divide mitotically, and five chromosomes are evident at metaphase. A mature sorus usually contains 5-20 sporangia, but more than 100 may be present in larger sori (fig. 23, $24,31)$. By the time the incipient sorus is multinucleate, a conspicuous plug is formed in the exitpore which attaches the sorus to the resting spore case, as described for the evanescent prosori (fig. $30,31)$. When the sorus with its attached spore case is placed in water, it floats, this fact indicating the possibility that the attached spore case may function as a buoy and facilitate the dissemination of sporangia in water. The maturation of the sporangia as well as sporogenesis are similar to the corresponding processes in sporangia derived from the evanescent prosori. However, sporogenesis does not occur in the sporangia which remain in the water in which the resting spores germinated, even when conditions are very favorable. Nevertheless, they remain viable in such fluid as long as two weeks, or for three weeks on moist agar plates, at $21^{\circ} \mathrm{C}$. When the mature sori are individually picked out and placed in fresh charcoal-treated water they produce planospores readily. This indicates, as Kusano (1930a) suggested for S. fulgens, that germinating resting spores might produce 
some toxic substances which inhibit sporogenesis. The planospores, however, are not adversely affected when placed in such water.

Planospores derived from sporangia which were obtained from the germinated resting spores and evanescent prosori are alike and behave similarly. In electron micrographs (fig. 50-56) the structure of the flagella is similar to that well known as the whip-lash type. The swollen tips of the flagella are conspicuous, as shown in Physoderma pulposum (Wallr.) Karling (Yamuna Lingappa, unpublished). In most pictures, the tapering ends of the flagella are sharply bent to one side (fig. 50-54). The disintegrating flagella show more than nine fibrils. During absorption, the flagella become thick and progressively short (fig. 52 ). It may be pointed out here that Heim (1956) reported the planospores of $S$. endobioticum to be myxamoebae and lacking flagella. She held that previous workers had mistaken the long pseudopodia of the "myxamoebae" for true flagella. Kusano (1930a) reported that the planospores of $S$. fulgens drop their flagella when they become sedentary. The electron micrographs, it is hoped, will clearly show that each planospore of $S$. brownii possesses a true whip-lash flagellum which either is gradually absorbed or disintegrates after the cessation of motility.

The planospores derived from the germinating resting spores do not aggregate into large clumps but form occasional pairs and fuse to give rise to zygotes. When a suspension of planospores or mature sporangia is placed on the host plants, a few resting spores are usually produced along with numerous evanescent prosori, sori and sporangia. Kusano (1930a) also found in S. fulgens that the planospores derived from the summer spores as well as those from the germinating resting spores were capable of functioning as gametes. In $S$. endobioticum, on the other hand, Curtis (1921) believed that the planospores from the germinating resting spores functioned only asexually as zoospores.

Abnormal Cytology in s. Brownil.-During the cytological study of the developmental stages of the evanescent prosori and resting spores, features have been observed in specially-treated infected leaves which may be interpreted as primary nuclei without membranes (fig. 32, 36), nuclear gemmation (fig. 33, 34, 37, 44, 49), heteroschizis (fig. $40,44)$ and reconstruction of secondary nuclei from extruded chromidia (fig. 34, 37). In addition, what looks like simple fission or amoeboid constriction (fig. 35, 39, 45, 48), fusion of small secondary nuclei (fig. 37), macro- and micro-nuclei (fig. 33, 34, 37) and degeneration of the primary nuclei (fig. 32-39) also have been found. However, the abnormal nuclei occur only in the degenerating thalli and fruiting bodies and obviously are pathological manifestations. In such thalli, pro- sori, sori, sporangia and resting spores the cytoplasm loses its typical appearance, consistency and stainability. It appears curdled, unevenly frothy and moribund (fig. 32, 39). One or more pluglike ingrowths may develop in the walls of the evanescent prosori and incipient sori (fig. 39). Experimentally such symptoms were induced by keeping the infected leaves under distilled water for $5-10 \mathrm{hr}$. at $35^{\circ} \mathrm{C}$., or by air-drying at $5-35^{\circ} \mathrm{C}$. In the materials so treated, the cytological abnormalities were observed in the thalli, prosori and sporangia, but not in the resting spores. Nevertheless, the resting spores also were affected similarly when killed by injury and heat. Under normal growing conditions, injury to the fungus bodies or to the host cells by fungi or insects brings about such abnormalities (fig. 39). However, any damage done to the host cells or to the host plant does not affect the mature resting spores. Occasionally, evanescent prosori were found to develop vesicles outside of the host cells (fig. 32). They were reproduced experimentally by pin-pricks into the living evanescent prosori which caused their contents to flow out and to form vesicular masses on the host surface. Such abnormal vesicular outgrowths, however, do not develop any further. All moribund fungal bodies show pathological mitosis (fig. 32-49), as described by Politzer (1934) for other organisms.

Discussion.-In S. brownii, previous studies by the author (1958a, b) showed that the thalli derived from the zoospores develop into the evanescent prosori, whereas those from the zygotes develop into resting spores. Previously, Curtis (1921) and Kusano (1930a, b) had reported the same ontogeny in S. endobioticum and S. fulgens, respectively. However, Heim (1956) reported recently that the resting spores of $S$. endobioticum are not the result of copulation of motile isogametes as, described by Curtis (1921) and Köhler (1930). Instead, she maintains that the ordinary vegetative (summer) spores become surrounded by a yellowish brown thick membrane ow. ing to unfavorable conditions of light, temperature and humidity, and undergo rest. Heim described intrasporangial fusion of secondary nuclei followed by meiotic divisions of the diploid nuclei. She even believed that the development of prosori, as described by Curtis (1921), is unnatural, brought about by excessive wetting and rapid desiccation. In fact, all Mme. Heim's original observations on the development and cytology of $S$. endobioticum are radically different from those described by all previous workers, and it is doubtful that they will be confirmed.

In $S$. brownii, as in other previously studied species, the development of individual zoospores and zygotes has not been followed continuously in single-spore cultures from the time of infection to their maturation. Therefore, the probability of 

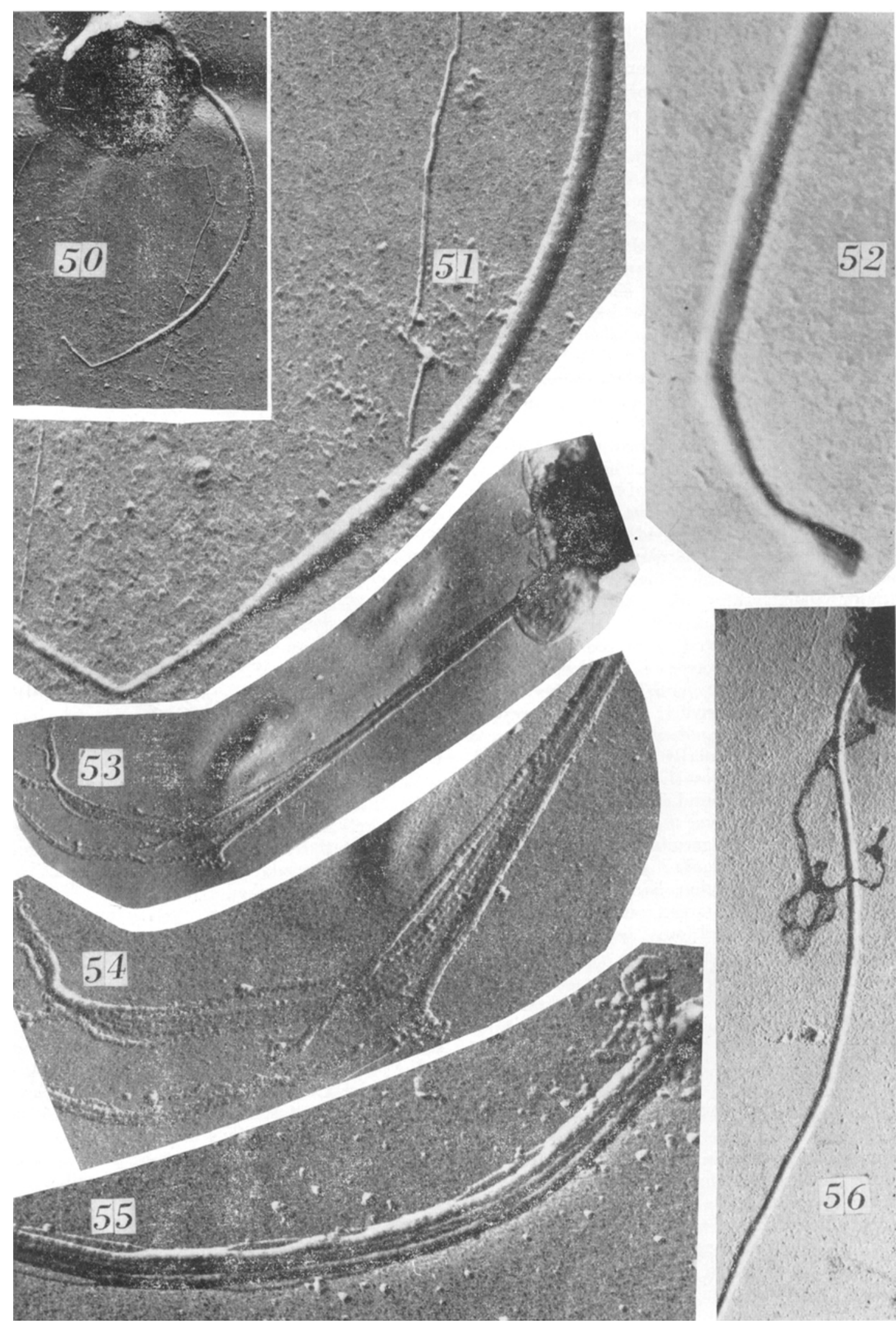
parthenogenetic development of the resting spores from zoospores cannot be ruled out. The occurrence of unusual colorless resting spores, which have characters intermediate between the evanescent prosori and the normal resting spores, nevertheless, suggests such development. However, this seems remote, because both resting spores and evanescent prosori often occur within the same host cells (fig. 20). In such mixed infections, under the common environment within the host cell, the two kinds of thalli develop differently, indicating that their origins were different. Furthermore, by their characteristic appearance and staining reactions, the early developmental stages of zygotes are distinguishable from those of zoospores. These differences have facilitated continuous observations of successive developmental stages of both generations, and formulation of the view that the evanescent prosori originate from zoospores, while the resting spores are zygotic in origin.

In $S$. brownii, fusion of haploid nuclei has been observed in the zygotes, but meiosis has not been observed during the germination of the resting spores. Divisions of the secondary nuclei in the incipient sori and sporangia resemble those of the corresponding stages of the evanescent prosori. Furthermore, planospores derived from the resting spores, as well as those from the evanescent prosori, behave similarly. This indicates that meiosis might have occurred in the first two divisions of the primary nucleus of the germinating resting spores, and that the expression of sex is phenotypic. In both $S$. brownii and $S$. fulgens, the basic chromosome number is known to be 5 (Lingappa, 1958a; Kusano, 1930b) and details of divisions are essentially similar. In spite of intensive cytological studies, meiosis and mitosis in the germinating resting spores of $S$. endobioticum are still unknown. So far, only Kusano (1930b) has observed meiosis in the germinating resting spores of Synchytrium, and the evidence obtained in $S$. brownii indicates that it occurs at the same stage in this species also.

During the development of the resting spores, the nucleoli extrude chromatic substances into the nuclear cavity. These pass to the protoplasm through the nuclear membrane in the same manner as described for the evanescent prosori (Lingappa, 1958a). Recent electron-microscope studies by Anderson and Beams (1956) and others have confirmed the existence of pores in the nuclear membranes through which the nucleolar discharges escape into the protoplasm. Such extrusion of chromatic materials into the protoplasm has been reported in other Synchytrium species also. This led Bally (1911), Tobler-Wolf (1912), Curtis (1921) and others to assume that the extruded nuclear substances give rise to secondary nucleia revival of Schleiden's theory of free-cell formation and the subsequent chromidial hypothesis. In view of the present knowledge of cytology, such hypotheses need no longer be taken seriously. It has been observed in $S$. brownii that at peak periods of discharge, deeply-staining granules accumulate adjacent to the primary nuclei, and give false impressions of nuclear gemmation or budding. However, these granules ultimately develop into characteristic cytoplasmic aggregates which are very abundant in the resting spores. These were evidently mistaken for zoospore initials by Bally (1919) and Curtis (1921) in S. endobioticum, and Munasinghe (1955) in S. desmodiae. Their gradual disappearance during germination of the resting spores of both $S$. brownii and $S$. fulgens leads to the conclusion that they are reserve food globules.

Various unusual cytological features were observed in the moribund prosori and resting spores of $S$. brownii which resembled those reported previously by Stevens (1907), Griggs (1908, 1909a, b), Bally $(1911,1919)$ and others in several species of Synchytrium. There were several stages which could be interpreted as amitotic divisions as described by Dangeard (1890), Rosen (1893), Bally (1911) and others. Some stages also simulated those described by the proponents of the chromidial hypothesis (Kusano, 1907; Percival, 1910; Bally, 1911; Curtis, 1921; and Quintanilha, 1926). They were found in moribund prosori, sori and resting spores, and they are regarded as pyknotic nuclei in various stages of degeneration. Previously, Rytz (1917) had dismissed the unusual cytological features in Synchytrium as relating to artifacts brought about by faulty technique, or by differences in tension between the nuclei and the fixing fluids. Evidently, Rytz did not correctly explain the abnormal cytology in Synchytrium. Later, Kusano (1930b) regarded the unusual cytology in Synchytrium related to pathological materials.

Fig. 50-56. Electron micrographs of the flagella of planospores of Synchytrium brownii. Planospores were killed and fixed by exposure to osmium tetroxide fumes at definite time intervals after their emergence from sporangia. Room temperature was $25-27^{\circ}$ C.-Fig. 50. Normal, active planospore. Fixed $30 \mathrm{~min}$. after emergence. $\times 8000 .-$ Fig. 51. Same flagellum much enlarged. $\times 60,000,-$ Fig. 52. Flagellum of planospore which was fixed 3 hr. after emergence from sporangia. Many planospores in the suspension were sluggish. Apparently, the flagellum is being absorbed. $\times 60,000$. - Fig. 53, 54. Disintegrating flagella showing fibrils. Spores were sedentary for about 4 hr. $\times 20,000$ and 60,000 respectively.- - Fig. 55 . Less common type of disintegration of flagella. $\times 60,000 .-F i g$. 56. Normal intact flagellum. Spores were fixed soon after becoming sedentary. $\times 8000$. 


\section{SUMMARY}

In $S$. brownii, the zygotes develop into resting spores in about 12 days at $27^{\circ} \mathrm{C}$. Colorless spores frequently occur which appear intermediate between the normal resting spores and evanescent prosori, but their origin and function are not known. The resting spores function as prosori in germination. When they are kept wet at $20-27^{\circ} \mathrm{C}$., some of them begin to germinate within 15 days, and sporadic germination continues to occur for 3 years in such cultures. The electron micrographs of planospores show typical chytrid flagella which are made up of more than 9 fibrils. Treatments such as exposure to high temperature and mechanical injury to the prosori, sori and resting spores cause pyknosis of their nuclei. The pyknotic nuclei simulate the unusual cytological features reported for other Synchytrium species. Accordingly, the reports such as the amitotic origin of secondary nuclei by nuclear gemmation, heteroschizis and amoeboid constriction are considered artifacts.

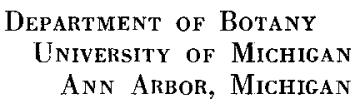

\section{LITERATURE CITED}

Andekson, E., AND H. W. Beams. 1956. Evidence from electron micrographs for the passage of material through pores of the nuclear membrane. Jour. Biophysic. Biochem. Cytol. 2: 439-444.

Bally, W. 1911. Cytologische Studien an Chytridineen. Jahr. Wiss. Bot. 50: 95-156.

- 1919. Einige Bemerkungen zu den amitotischen Kernteilungen der Chytridineen. Ber. Deut. Bot. Ges. 37: 115-122.

Curtis, K. M. 1921. The life-history and cytology of Synchytrium endobioticum (Schilb.) Perc., the cause of wart disease in potato. Phil. Trans. Roy. Soc. London, B. 210: 409-478.

Dangeard, P. A. 1890. Recherches histologiques sur les champignons. Le Botaniste 2: 63-150.

Grigcs, R. F. 1908. On the cytology of Synchytrium. III. The role of the centrosomes in the formation of the nuclear membrane. Ohio Nat. 8: 277-286.

- $1909 \mathrm{a}$. Some aspects of amitosis in Synchytrium. Bot. Gaz. 47: 127-138.

. 1909b. A note on amitosis by constriction in $S y n$ chytrium. Ohio Nat. 9: 513-515.

Heim, Panca. 1956. Remarques sur le développement, les divisions nucléaires et le cycle évolutif du Synchytrium endobioticum (Schilb.) Perc. Rev. de Mycol. 21: 93-120.

Karling, J. S. 1954. Synchytrium brownii, a new species with sexual reproduction. Sydowia 8: 27-30.

KöHLER, E. 1930. Beobachtungen an Zoosporenaufschwemmungen von Synchytrium endobioticum (Schilb.) Perc. Zentralblatt f. Bakt. 78: 222-241.

Kusano, S. 1907. On the nucleus of Synchytrium puerariae. Bot. Mag. (Tokyo) 21: 118-121.

- _ 1930a. The life-history and physiology of Syn- chytrium fulgens Schroet., with special reference to its sexuality. Japanese Jour. Bot. 5: 35-132.

. 1930b. Cytology of Synchytrium fulgens Schroet. Jour. Coll. Agric. (Tokyo) 10: 347-388.

LingaPPA, B. T. 1955. Resting spore germination in Synchytrium in relation to classification. Amer. Jour. Bot. 42: 841-850.

1958a. Development and cytology of the evanescent prosori of Synchytrium brownii Karling. Amer. Jour. Bot. 45: 1.16-123.

- 1958b. Sexuality in Synchytrium brownii Karling. Mycologia 50: (In press)

Munasinghe, H. L. 1955. A wart disease of Desmodium ovalifolium caused by a species of Synchytrium. Quart. Circ. Ceylon Rubber Res. Inst. 31: 22-28.

Percival, J. 1910. Potato wart disease: The life-history and cytology of Synchytrium endobioticum (Schilb.) Perc. Centralbl. Bakt. II Abt. 25: 440-447.

Politzer, G. 1934. Pathologie der Mitose. Protoplasma Monogr. 7. Gebrüder Borntraeger. Berlin.

Quintanilha, A. 1926. Contribuicao ao estudo dos Synchytrium. Bol. Soc. Broteriana. II. 3: 1-110.

Rosen, F. 1893. Beiträge zur Kenntnis der Pflanzenzellen. II. Studien übor die Kerne und die Membranbildung 6: $237-266$. bei Myxomyceten und Pilzen. Beiträge Biol. Pfanzen

Rytz, W. 1917. Beiträge zur Kenntnis der Gattung Synchytrium. 1. Fortsetzung. Die cytologischen Verhältnisse bei Synchytrium taraxaci de By. et Wor. Beih. Bot. Centralblatt II Abt. 34: 343-372.

Stevens, F. L. 1907. Some remarkable nuclear structures in Synchytrium. Ann. Mycol. 5: 480-484.

Tobler-Wolf, G. 1912. Die Synchytrien. Arch. Protistenk. 28: 141-238. 